DOI: $10.19195 / 2082-8322.7 .8$

Karina Stasiuk-Krajewska

SWPS Uniwersytet Humanistycznospołeczny

Wrocław

\title{
Komunikacja lekarz-pacjent \\ a wizerunek lekarzy \\ i podmiotów zdrowia publicznego
}

Negatywny wizerunek systemu opieki zdrowotnej i lekarzy w Polsce uznaje się za oczywisty. Dowodzą tego nie tylko powszechnie i w różnych kontekstach formułowane przekonania (płynące zarówno z wewnątrz, jak i zewnątrz sytemu) dotyczące owego negatywnego wizerunku oraz głosy wskazujące podmioty i zjawiska za ten stan rzeczy odpowiedzialne ${ }^{1}$. Nawet pobieżna analiza mediów zdaje się to potwierdzać. Nie ulega wątpliwości, że w przekazach medialnych dominują te, które są wobec lekarzy (i systemu opieki zdrowotnej - choć to nie to samo, o czym za chwilę) krytyczne, które - prawdopodobnie - negatywnie wpływają na wizerunek zarówno personelu medycznego (profesji medycznych), jak i systemu jako takiego.

Sprawa nie jest jednak aż tak jednoznaczna. Dokładniejsza i profesjonalnie wykonana analiza mediów wskazuje na to, że czym innym jest wizerunek medialny systemu opieki zdrowotnej, czym innym zaś wizerunek lekarza. Już na początku rozważań warto więc przytoczyć zasadnicze rozróżnienie: wizerunek lekarza nie jest wizerunkiem systemu zdrowia publicznego, dodatkowo jeszcze oba te konstrukty, wyobrażenia społeczne odróżniają się wyraźnie do wizerunku pielęgniarki, który nie będzie przedmiotem mojego zainteresowania w niniejszym tekście. Niewątpliwie jednak wszystkie trzy wizerunki - lekarza, pielęgniarki i systemu - wzajemnie na siebie wpływają i pozostają w wyraźnych relacjach. Nie są jednak z sobą tożsame.

1 Świetnie wątki i stan dyskusji na ten temat podsumowują wypowiedzi na forum „Gazety Wyborczej”, http://forum.gazeta.pl/forum/w,305,83303428,,Jaki_powinien_byc_wizerunek_lekarza_w_mediach_html?v=2 [dostęp: 6 marca 2016]. 
Tezę tę potwierdza też analiza wyników badań opinii społecznej. Komunikat z badań CBOS z marca 2012 roku wskazuje osiem obszarów, które da się wyróżnić w ocenie lekarzy i opieki zdrowotnej, formułowanej przez respondentów ${ }^{2}$. Wśród nich znajduje się obszar określony jako „jakość leczenia, a więc kompetencje lekarzy i ich ogólny stosunek do pacjentów" (do obszaru tego włączono następujące zmienne: lekarze angażują się w swoją pracę — zależy im na tym, aby pomóc pacjentom; wszyscy pacjenci są równo traktowani, zależnie jedynie od ich stanu zdrowia; pacjenci są traktowani z życzliwością i troską; lekarze są kompetentni — znają się na tym, co robią). Obszar ten jest prezentowany, oprócz dostępności usług lekarzy podstawowej opieki zdrowotnej, nowoczesności aparatury medycznej (a także, z mniejszym współczynnikiem, pomoc w nagłych sytuacjach i brak dodatkowych opłat) jako jedna $\mathrm{z}$ mocnych stron systemu opieki zdrowotnej (współczynnik $+0,12$; por. rysunek 1 ).

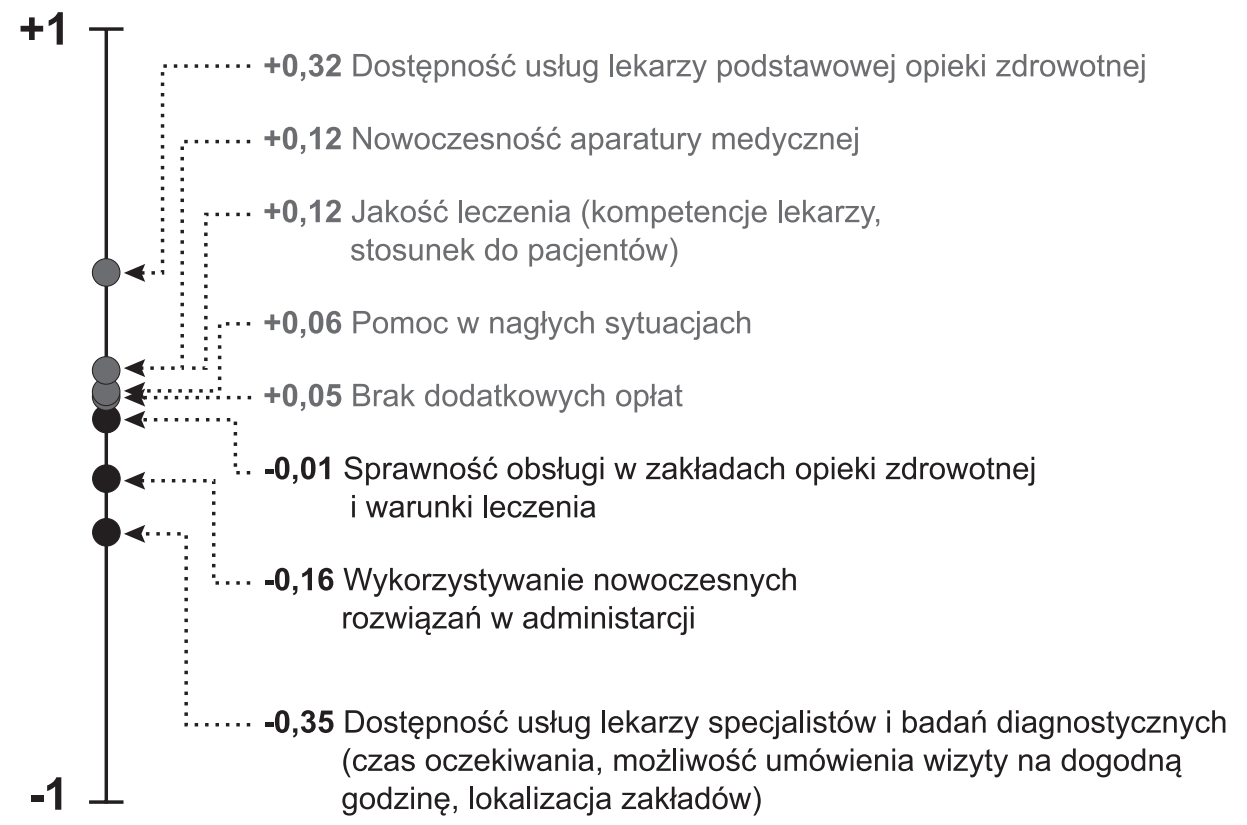

Rysunek 1. Słabe i mocne strony opieki zdrowotnej

Źródło: CBOS, Opinie o funkcjonowaniu opieki zdrowotnej, Warszawa, marzec 2012, http://cbos.pl/SPISKOM. POL/2012/K_034_12.PDF.

Wydaje się więc, że opinia na temat lekarzy (budowana na podstawie wskazanych powyżej zmiennych szczegółowych, które mają w istocie charakter komunikacyjny) jest znacznie lepsza niż opinia na temat opieki zdrowotnej jako takiej. Tę konstatację potwierdza analiza szczegółowa opinii wyrażanych w związku z cytowanymi zmiennymi:

2 CBOS, opinie o funkcjonowaniu opieki zdrowotnej, Warszawa, marzec 2012, http://cbos.pl/SPISKOM.POL/2012/K_034_12.PDF. 
— lekarze angażują się w swoją pracę — zależy im na tym, aby pomóc pacjentom: $61 \%$;

— wszyscy pacjenci są równo traktowani: $44 \%$;

- pacjenci są traktowani z życzliwością i troską: 54\%;

- lekarze są kompetentni - znają się na tym, co robią: 68\%.

Autorzy raportu podsumowują:

Wiele przemawia za tym, że krytyczny stosunek do służby zdrowia, bardziej niż w osobistych doświadczeniach, zakorzeniony jest w tym, co i jak się mówi na jej temat, a wystawiana przez badanych ogólna ocena wydaje się raczej głosem opinii publicznej niż ich własnym ${ }^{3}$.

Interpretacja ta wydaje się zbyt optymistyczna, a cytowane wyniki wskazują raczej na to, że w świadomości respondentów istnieje zasadnicze rozróżnienie na system opieki zdrowotnej i lekarza-specjalistę, z którym bezpośrednio styka się pacjent. Tych dwóch wyobrażeń, tych dwóch wizerunków i opinii nie można utożsamiać. Wizerunek lekarza zdaje się zdecydowanie lepszy od wizerunku systemu opieki medycznej. Ale czy można powiedzieć, że jest dobry? Wyniki badań nie są jednoznaczne. HealthぬSociety Barometer $2013^{4}$ wskazuje, że badani negatywnie oceniają umiejętności zawodowe lekarzy w Polsce, głównie w kontekście błędów medycznych. Współczynnik wynosi 4,7 na 10. Jest to wynik najgorszy wśród krajów uczestniczących w badaniu, należy jednak podkreślić, że średnia w tych krajach nie jest znaczącą wyższa - wynosi bowiem 5,6. Co więcej, organizacja polskiego systemu opieki zdrowotnej została oceniona (w tej samej skali) na 2,8. Nadal więc widać wyraźną różnicę na korzyść lekarzy i ich wizerunku w zestawieniu z oceną systemu opieki zdrowotnej jako takiego.

Z drugiej jednak strony badanie European Trusted Brands wskazuje na stosunkowo niski stopień zaufania do zawodu lekarza $(57 \%$ w porównaniu ze średnim wynikiem 76\%) - lekarze znajdują się na 6. miejscu z 20 uwzględnionych zawodów ${ }^{5}$. Z kolei respondenci pytani o prestiż zawodu lekarza odpowiadają już inaczej: 71\% respondentów darzy ten zawód dużym poważaniem (choć wyżej plasuje się strażak, profesor uniwersytetu, inżynier pracujący w fabryce, nauczyciel, a także górnik, robotnik wykwalifikowany i pielęgniarka). Być może ten stosunkowo niski wynik powiązać można z szerszym zjawiskiem typowym społeczeństwu polskiemu - ograniczonym wskaźnikiem zaufania jako takiego. $\mathrm{W}$ tym sensie respondenci w ogóle niechętnie przyznają, że ufają komukolwiek (lub czemukolwiek). Warto przy tym zauważyć, że prestiż zawodu lekarza, choć ma tendencję spadkową, pozostaje jednak

3 Ibidem, s. 19.

${ }^{4}$ Health and Society Barometer - Europ Assistance / CSA, 2013: $7^{\text {th }}$ wave of the barometer, http://www.europ-assistance.com/sites/default/files/health__society_csa_europ_assistance_barometer_2013_full_report.pdf [dostęp: 6 marca 2016].

${ }_{5}$ Reader's Digest, Eurpeat Trusted Brands 2013, por. np. http://www.marketing-news.pl/message. php?art=38238 [dostęp: 6 marca 2016]. 
wciąż na stosunkowo wysokim i stabilnym poziomie: od 79\% w 1995 roku do 71\% w 2013 roku. Wysoki prestiż zawodu lekarza zdają się także potwierdzać komentowane przez media badania Dominiki Maison, z których wynika, że zawód lekarza cieszy się najwyższym prestiżem społecznym w grupie kobiet (86\% wskazało, że to bardzo pożyteczny zawód, większość matek zaś deklarowała, że najchętniej w roli męża dla swej córki widziałaby właśnie lekarza, choć za własnego męża chciałyby przedsiębiorcę) ${ }^{6}$. Jednakże w kontekście oceny profesjonalizmu lekarzy niepokojące wydają się rezultaty badań TNS Polska, z których wynika, że lekarz jest autorytetem w dziedzinie zdrowia dla $27 \%$ respondentów, podczas gdy przyjaciele i znajomi dla $19 \%$, a Internet dla $12 \%^{7}$ (Budowanie wizerunku w ochronie zdrowia na przykładzie lekarzy w Polsce). Jak widać, różnica nie jest imponująca.

Kwestia wizerunku lekarza wydaje się zatem, w odróżnieniu od problemu wizerunku systemu opieki medycznej, niejednoznaczna. Wynika to zapewne, między innymi, z faktu niejednoznaczności (dla respondentów) pojęć takich, jak zaufanie, prestiż czy autorytet. Prawdopodobnie też kategorię zaufania respondenci odnoszą raczej do całości systemu opieki zdrowotnej (w istocie bowiem nie chodzi tu o przekonanie dotyczące kompetencji lekarza, ale efektywności działania systemu jako takiego), kategorię prestiżu zaś traktują bardziej indywidualnie, personalnie, „ludzko” - by tak rzec.

Wydaje się nie ulegać wątpliwości, że w przypadku wizerunku lekarza zaufanie jest istotną zmienną. Wynika to ze społecznej funkcji tej profesji, zwłaszcza zaś z postrzegania jej jako zawodu wysokiej społecznej odpowiedzialności, w związku z tym wysokiego zaufania społecznego. Mówiąc krótko, opinia na temat lekarzy, ich wizerunek pozostaje $\mathrm{w}$ zasadniczym związku $\mathrm{z}$ odczuwanym wobec lekarzy zaufaniem (korelację tę pokazują np. wyraźnie badania Joanny Turkiewicz ${ }^{8}$ ). Nie wchodząc tutaj w skomplikowaną kwestię definiowania zaufania jako zjawiska społecznego, warto zwrócić uwagę na jego ewidentnie komunikacyjny charakter. Zaufanie jest bowiem zjawiskiem budowanym w toku interakcji, uznajemy kogoś za godnego zaufania (lub nie), analizując jego/jej zachowania komunikacyjne, interpretując je jako budujące pewien rodzaj relacji między nami a tym, komu ufamy.

Kiedy Joanna Turkiewicz konstruuje indeks zaufania do lekarza, włącza do niego następujące zmienne9:

1. korzystając z opieki tego lekarza, czuję się bezpiecznie;

2. mogę pozwolić sobie na otwartość i szczerość oraz przyznawanie się do popełnionych błędów bez obaw o reakcję tego lekarza;

${ }^{6}$ Por. K. Domaradzki, Polki uwielbiaja przedsiębiorców, http://kariera.forbes.pl/polki-uwielbiaja-przedsiebiorcow,artykuly,164274,1,1.html [dostęp: 6 marca 2016].

7 TNS Polska, Zdrowy styl życia Polaków, 2012, cyt. za: J. Turkiewicz, Budowanie wizerunku w ochronie zdrowia na przykładzie lekarzy w Polsce, „Journal of Health Sciences” 2013, nr 3 (11), s. 133-142.

8 Por. ibidem.

9 Ibidem. 
3. wykonuję polecenia tego lekarza, nawet te trudniejsze i wymagające wysiłku;

4. bez obaw zadaję pytania temu lekarzowi;

5. decyzje tego lekarza nie wzbudzają mojego oporu.

Zmienne te odsyłają do podstawowych standardów komunikowania lekarza z pacjentem. Idąc dalej, autorka wymienia czynniki bezpośrednio wpływające na wizerunek lekarza. W istocie tylko jeden z tych czynników (trafność diagnoz/skuteczność planu leczenia, zresztą o najmniejszym współczynniku korelacji) ma charakter pozakomunikacyjny (w znaczeniu niepowiązany z oceną odnoszącą się do interakcji, do „wrażenia z komunikacji”, gdyż w szerszym znaczeniu jest on oczywiście komunikacyjny - o tyle, o ile wszystko co społeczne jest komunikacyjne). Pozostałe czynniki wiążą się bezpośrednio z oceną interakcji: odczuwany szacunek ze strony lekarza, poświęcenie wystarczającej uwagi pacjentowi; udzielenie emocjonalnego wsparcia, powitanie - wstanie zza biurka i podanie ręki, zrozumienie informacji o leczeniu przez pacjenta; przestrzeganie praw pacjenta (które, zauważmy, są w znacznym stopniu prawem do informacji i szacunku). Dodatkowo autorka wspomina też o organizacji przestrzennej gabinetu, marginalizując nieco tę kwestię i wiążąc ją raczej z budowaniem autorytetu (np. przez eksponowanie dyplomów na ścianach gabinetów) ${ }^{10}$. Zauważmy jednak, że organizacja przestrzeni, zwana w teorii komunikacji proksemiką, jest zasadniczym elementem wpływającym na ocenę interakcji i uczestników tej interakcji - zwłaszcza w zakresie wzajemnych relacji, poczucia bezpieczeństwa i sympatii. Pojawienie się tego czynnika w ocenie wizerunku lekarza też ma znaczenie komunikacyjne.

Podobnie jest z obszarem „kompetencji lekarzy i ich ogólnego stosunku do pacjentów". Pojawiające się tutaj zmienne szczegółowe mają zasadniczo komunikacyjny charakter: pacjenci są traktowani z życzliwością i troską, lekarze angażują się w swoją pracę, zależy im na pacjentach, pacjenci są równo traktowani. Także zmienna „lekarze są kompetentni" jest w istocie komunikacyjna - pacjenci bowiem nie są w stanie w sposób formalny ocenić kompetencji lekarza (nie posiadają odpowiedniej wiedzy), prawdopodobnie więc oceniają nie tyle jego medyczne kompetencje, ile kompetencje komunikacyjne, które ostatecznie powodują, że lekarz jest odbierany/interpretowany/dekodowany/konstruowany i oceniany jako kompetentny. Stawiając rzecz mocno, powiedzieć można, że kryterium komunikacyjne jest w istocie zasadniczym kryterium, jakim dysponuje pacjent, oceniając lekarza (z wyjątkiem być może efektywności zastosowanej metody leczenia, co także pozostaje w korelacji z realizowanymi standardami komunikacji lekarz-pacjent).

Kiedy więc zapytamy nie tyle o wizerunek sytemu opieki zdrowotnej, ile o wizerunek lekarza (a rozróżnienie to ma istotne znaczenie), dochodzimy do wniosku, że zasadniczym elementem konstytuującym ten wizerunek jest ocena kompetencji komunikacyjnych lekarza, ocena jego komunikacji z pacjentem. W dalszej kolejności

10 Ibidem. 
ocena ta, konstytuując wizerunek lekarza, ma też zasadnicze znaczenie w ocenie i wizerunku systemu opieki zdrowotnej, choć tutaj ważne pozostają także inne zmienne (na marginesie dodajmy, że niektóre mają też ściśle komunikacyjny charakter, np. obsługa pacjentów przez administrację placówek medycznych).

Tezę tę potwierdzają wyraźnie np. opinie wypowiadane przez pełnomocników ds. pacjenta z wrocławskich szpitali (jeśli oczywiście tacy istnieją i jeśli chcą rozmawiać z mediami). „Pielęgniarka była arogancka, lekarz nie chce nic powiedzieć, dokumentacja nie do skopiowania, a telefonu w rejestracji nikt nie odbiera. W takich sprawach interweniują pełnomocnicy ds. pacjenta. Przeczytaj, do kogo się zwrócić we wrocławskich szpitalach"11 — rozpoczyna poświęcony temu zagadnieniu tekst Edyta Bryła.

Pacjenci czasem pytają, dlaczego kolejki są aż tak długie. Nie mają pewności, czy opieka nam nimi jest właściwa. Ale najczęściej pacjenci skarżą się na to, że personel jest niemiły i arogancki. Dotyczy to zarówno pracowników recepcji, jak i lekarzy czy pielęgniarek, choć tych ostatnich w najmniejszym stopniu. Pacjenci często skarżą się na arogancję pracowników szpitala ${ }^{12}$

— opowiada dziennikarce Maria Dytko z Wojewódzkiego Szpitala Specjalistycznego we Wrocławiu.

Podobnie znaczna część krytycznych materiałów obecnych w mediach, dotyczących służby zdrowia, odnosi się w istocie do standardów komunikowania lekarz-pacjent. Tego rodzaju kwestie interesują media, ponieważ pozostają w zgodzie z ich systemowymi oczekiwaniami i preferencjami: są tu emocje, jest indywidualny człowiek w konflikcie z dominującym systemem (lub przedstawicielem tego systemu), jest odniesienie do codziennych doświadczeń czytelników. Są wreszcie „smaczne” cytaty, które można wykorzystać w tytule. Charakterystycznym przykładem jest materiał Ginekolog do pacjentki: Czemu się pani tak boi, jakby pania ktoś zgwatcił ${ }^{13}$ (wszystkie komentarze pod tekstem są negatywne, większość odnosi się do standardów komunikacji). Istnieje więc zasadnicza korelacja między wizerunkiem lekarzy a ich kompetencjami komunikacyjnymi. Można nawet stwierdzić, że tym, co zasadniczo wpływa na opinię pacjentów o lekarzach (zwłaszcza na zaufanie do nich) są stosowane przez nich, lekarzy, standardy komunikacji interpersonalnej, albowiem to właśnie narzędzia komunikacyjne budują zaufanie, symetryczną relację, poczucie bezpieczeństwa i szacunku u pacjenta.

Obserwacje te znajdują potwierdzenie w licznych badaniach prowadzonych za granicą. Już publikacja Amerykańskiego Instytutu Medycyny z 2001 roku wykazała

11 http://wroclaw.gazeta.pl/wroclaw/1,35771,15910597,Skargi__wnioski_i_pytania__Od_pacjentow_przyjma_je.html\#LokWrocTxt\#ixzz311T3up50 [dostęp: 6 marca 2016].

12 Ibidem.

13 http://www.edziecko.pl/rodzice/12,133102,15875501,Ginekolog_do_pacjentki_Czemu_sie_ pani_tak_boi_jakby.html\#BoxSlotII3img [dostęp: 6 marca 2016]. 
zasadniczą rolę czynników komunikacyjnych w ocenie jakości opieki medycznej ${ }^{14}$. Badania wskazywały, że elementami niezbędnymi do świadczenia wysokiej jakości usług były: poczucie bezpieczeństwa pacjenta, punktualność, skuteczność, wydajność i sprawiedliwość lekarza oraz skoncentrowanie przez niego wagi na pacjencie. Kolejne badania potwierdzały wymienione wcześniej czynniki, wskazując jednocześnie na wzrastającą rolę zmiennej określanej mianem relacji między lekarzem a pacjentem. „Poprzez rozmowę, piszą Debra L. Roter and Judity A. Hall, lekarze i pacjenci wyrażają, kim są, czego od siebie wzajemnie oczekują i w jaki rodzaj relacji wchodzą"15.

Komunikacja lekarz-pacjent jest, co wobec powyższego nie dziwi, przedmiotem licznych badań, analiz i publikacji, także w Polsce. Widać jednak zasadniczą dysproporcję między badaniem i analizowaniem tego zagadnienia na świecie a tym, jak interpretuje się, a zwłaszcza implementuje w praktyce zagadnienia komunikacji lekarz-pacjent w Polsce. Istnieje tu zasadnicza dysproporcja dotycząca badań empirycznych, liczby i zakresu publikacji, edukacji i intensywności szkoleń ${ }^{16}$. Na świecie istnieją w tym zakresie także rozmaite akty normatywne mające charakter pewnego rodzaju dobrowolnych samoregulacji (np. MAAS Global rating list for doctor patient communication skills ${ }^{17}$, Toronto consensus statement ${ }^{18}$ czy tzw. Kalamazoo Consensus Statement, na bazie którego powstały standardy oceny komunikacji lekarza z pacjentem ${ }^{19}$ ). Istotą tego rodzaju dokumentów jest wyznaczanie standardów komunikacji między lekarzem a pacjentem przez uczynienie owych standardów mierzalnymi. W tym zakresie jest to zasadnicza kwestia dla praktyki. Jak zawsze w przypadku narzędzi z zakresu systemów samoregulacji (np. kodeksów etycznych) - im większa precyzja standaryzacji, im konkretniejsze sformułowanie kryteriów, tym narzędzie lepiej służy praktykom dla oceny ich profesjonalnych kompetencji. Ewaluacja ta zaś ma zasadnicze znaczenie dla kroków dalszych — zwłaszcza w zakresie doskonalenia kompetencji. Lista kontrolna zbudowana na podstawie wspomnianego Kalamazoo Consensus Statement składa się z siedmiu elementów, które poddaje się ocenie, od-

14 Por. W. Dworzański, A. Dworzańska, F. Burdan, Istota relacji lekarz-pacjent w budowaniu wizerunku placówki medycznej, „Pol. Merkuriusz Lek” 2012, nr 32 (187).

15 D.L. Roter, J.A. Hall, Doctors Talking with Patients. Patients Talking with Doctors, London Praegfer 2006, s. 5.

16 Poradniki, choć niewątpliwe bardzo przydatne, mają charakter wyrywkowy i nieco chaotyczny (por. np. M. Hebanowski, J. Kliszcz, B. Trzeciak, Poradnik komunikowania się lekarza z pacjentem, Warszawa 1999; Leczyć po ludzku, Efektywna komunikacja lekarza z pacjentem. Poradnik dla lekarzy o skutecznych metodach przełamywania barier w relacji z pacjentem, „, Gazeta Wyborcza”, http://bi.gazeta.pl/ $\mathrm{im} / 4 / 10135 / \mathrm{m} 10135204, L E C Z Y C-B R O S Z U R A . p d f)$, natomiast publikacje wprowadzające nieco więcej zagadnień teoretycznych bywają trudne do zastosowania w praktyce.

$17 \mathrm{http} / / /$ www.biomedcentral.com/content/supplementary/1471-2296-14-65-s1.pdf.

$18 \mathrm{http}: / /$ www.researchgate.net/publication/21394399_Doctorpatient_communication_the_Toronto_consensus_statement.

19 http://fd4me.osu.edu/lppreceptors/system/block_resource_items/resources/000/000/013/original/Kalamazoo_Comm_tool.pdf?1358177368. 
nosząc się do ich kilkupunktowych uszczegółowień. Dokument ocenia komunikację według następującej struktury ${ }^{20}$ :

1. Budowanie relacji:

- powitanie i okazanie zainteresowania pacjentowi jako osobie;

- używanie słów sygnalizujących zainteresowanie i uwagę podczas wywiadu;

- używanie odpowiedniego tonu, kontaktu wzrokowego i postawy, sygnalizujących uwagę i zainteresowanie.

2. Otwartość rozmowy:

- pozwolenie pacjentowi na opowiedzenie swojej historii bez przerywania mu;

- pytanie: „czy coś jeszcze?” - aby umożliwić pełne wypowiedzenie się pacjenta;

- wyjaśnianie/negocjowanie porządku wizyty.

3. Gromadzenie informacji:

- otwarcie się na historię pacjenta (tell me about);

- uzyskiwanie danych szczegółowych przy pomocy pytań tak/nie;

- podsumowywanie i dawanie pacjentowi szansy na korektę danych;

- efektywne przejście do pytań dodatkowych.

4. Zrozumienie perspektywy pacjenta:

- pytanie o wydarzenia z życia, okoliczności, innych ludzi, którzy mogli wpłynąć na stan pacjenta;

- uzyskanie wiedzy na temat przekonań pacjenta, jego obaw i oczekiwań związanych z leczeniem;

- reagowanie na wyrażane przez pacjenta idee i emocje.

5. Współdzielenie informacji:

- wspieranie rozumienia problemu przez pacjenta;

- zaspokajanie jego potrzeby informacji;

— wyjaśnianie używanych słów tak, by pacjent je rozumiał;

- sprawdzanie wzajemnego zrozumienia w zakresie diagnozy i planów leczenia;

- pytanie, czy pacjent ma dodatkowe pytania.

6. Osiąganie porozumienia:

- branie pod uwagę oczekiwań i wyborów pacjenta;

- pytanie o możliwości przestrzegania przez pacjenta zaleceń i realizowania leczenia.

7. Budowanie fazy zamknięcia:

— zapytanie o to, czy pacjent ma pytania, wątpliwości, uwagi;

- podsumowanie/ustalenie planów na następną wizytę;

- zaplanowanie dalszego kontaktu;

— podziękowanie i pożegnanie.

Tego rodzaju standardy oceny kompetencji komunikacyjnych, które szczególnie wyróżniają się stopniem uszczegółowienia i ukonkretnienia oraz uporządkowania

20 Ibidem. 
(co niewątpliwie czyni ich zastosowanie w praktyce nie tylko możliwym, ale też efektywnym), opierają się oczywiście na ogólniejszych, wartościujących założeniach, dotyczących tego, jak powinna wyglądać idealna/modelowa komunikacja lekarzpacjent. Na szczególnie pozytywną ocenę zasługuje Doctors Talking with Patients / Patients Talking with Doctors: improving Communications In medical visits Debry L. Roter and Judity A. Hall, które wymieniają osiem zasad właściwej komunikacji lekarz-pacjent (pacjent-lekarz) ${ }^{21}$ :

1. Komunikacja powinna realizować zasadniczą dla pacjenta „potrzebę opowiedzenia historii swojej choroby; historia ta powinna być wysłuchana przez lekarza"22. Jest to tzw. troublestelling, zachowanie komunikacyjne, które dla pacjenta i jego poczucia komfortu ma wiele istotnych funkcji: chory konstruuje w ten sposób chorobę i wiąże ją ze swoim światem; rekonstruuje swoją tożsamość w tym nowym kontekście; wyjaśnia i zyskuje poczucie zrozumienia swojej choroby; przekształca jednostkowe doświadczenie w zbiorowe; wreszcie osiąga partykularne cele (np. usprawiedliwienie, zrzeczenie się odpowiedzialności). Dzięki możliwości opowiedzenia swojej historii pacjent już na początku wizyty nabiera poczucia, że lekarz interesuje się nim jako człowiekiem, że on i jego problemy są dla lekarza sprawą istotną i wyjątkową. Z drugiej strony troublestellling pozwala lekarzowi zobaczyć, jak sam pacjent postrzega swoje dolegliwości, jak interpretuje ich przyczyny, jakie żywi odnośnie do nich przekonania. Wiedza ta jest bardzo istotna zarówno na etapie stawiania diagnozy, jak i projektowania przebiegu leczenia. To z kolei prowadzi do kolejnego ważnego punktu.

2. Komunikacja powinna umożliwić pacjentowi zaprezentowanie „szczegółowego wglądu i szczególnej wiedzy"23, jakie posiada on (i tylko on - jako pacjent właśnie) na temat swojego stanu zdrowia i samopoczucia. Formalnie w relacji lekarz-pacjent ekspertem jest oczywiście lekarz. Należy jednak pamiętać, że ów brak równowagi (najprawdopodobniej na poziomie wiedzy profesjonalnej konieczny) czyni komunikację niesymetryczną, a tym samym trudniejszą i mniej satysfakcjonującą dla tego, kto w tej niesymetrycznej relacji znajduje się w gorszej pozycji, a więc dla pacjenta. Traktowanie pacjenta jako eksperta w zakresie, w którym niewątpliwie nim jest (jego własnego samopoczucia, jego własnej historii i życia), czyni ową immanentną nierównowagę relacji lekarz-pacjent nieco bardziej zrównoważoną. W ten sposób pacjent dokonuje swoistej samooceny stanu swojego zdrowia, często także stawia pewien rodzaj diagnozy. Bywa to dla lekarza irytujące (właśnie z powodu zagrożenia jego komunikacyjnej dominacji w relacji z pacjentem), okazuje się jednak przydane nie tylko do poprawy komunikacyjnej pozycji pacjenta (i jego samopoczucia oraz satysfakcji z wizyty), ale także do podniesienia efektywności procesu stawiania diagnozy i leczenia.

${ }^{21}$ D.L. Roter, J.A. Hall, op. cit.

22 Ibidem, s. 7.

${ }^{23}$ Ibidem. 
3. Komunikacja powinna „ułatwiać rozpoznanie relacji między stanem psychicznym pacjenta a jego fizycznym odczuwaniem choroby" ${ }^{24}$. Wiele $-\mathrm{w}$ rzeczywistości większość - symptomów medycznych, w związku z którymi pacjent poszukuje porady medycznej, nie może być powiązana ze specyficzną diagnozą. Przyczyną tej niemożności jest fakt, że nie są to w istocie symptomy choroby, ale „reakcje na życie. Bóle głowy, wysypki, zawroty głowy, wyczerpanie, zaburzenia żołądkowe, bóle, chroniczne zaparcia lub biegunki czy wahania wagi mogą równie dobrze stanowić reakcję na problemy życiowe, a nie symptomy określonej choroby" ${ }^{25}$. Stąd szczególnie istotne jest rozpoznanie stanu psychicznego pacjenta, co wydaje się bardzo trudne czy wręcz niemożliwe, jeśli komunikacja lekarz-pacjent przebiega z istotnymi zaburzeniami.

4. Komunikacja powinna maksymalizować użyteczność wiedzy eksperckiej lekarza. Oczywiście, pacjent przychodzący do lekarza oczekuje przede wszystkim informacji o charakterze specjalistycznym - informacji, do której on, nie będąc lekarzem, nie ma dostępu. Dlatego też „obowiązkiem lekarzy jest dzielić się swoją specjalistyczną wiedzą medyczną w taki sposób, aby informacja była jasna, relewantna i użyteczna dla pacjenta"26. Druga część zalecenia jest tu zasadnicza. Jej nierespektowanie pozostaje w wyraźnej korelacji nie tylko z brakiem poczucia bezpieczeństwa u pacjenta i jego niskim zaufaniem do lekarza, lecz także ze zmiennymi, które mogą wydawać się dużo bardziej istotne z punktu widzenia efektywności procesu leczenia - np. $\mathrm{z}$ nieprzestrzeganiem zaleceń lekarskich. Jeśli pacjent nie będzie miał poczucia sensowności tego, co nakazał lekarz, nie zinternalizuje tego jako uzasadnionego i dającego perspektywę lepszego samopoczucia sposobu postępowania - prawdopodobieństwo zmiany nawyków czy konsekwentnego stosowania zaleceń zdecydowania spada. Jak się wydaje, także popularność stawiania diagnoz i leczenia się „przez internet" wynika $\mathrm{z}$ tego, że wchodząc na przykład na rozmaite fora internetowe czy szerzej - czytając wypowiedzi w Internecie (laików, lecz także specjalistów, którzy za pośrednictwem tego medium, z różnych zapewne powodów, komunikują w sposób mniej hermetyczny) - mamy poczucie zrozumiałości, użyteczności uzyskanych informacji. W tym komunikacyjnym kontekście czujemy się bezpieczniej, „symetryczniej" - jesteśmy w stanie odnieść uzyskane informacje czy opinie do własnego codziennego życia, do własnych doświadczeń.

5. Komunikacja powinna uznawać i wspierać emocjonalne aspekty relacji. Komunikacja ze swej istoty jest emocjonalnie istotna: „wyrażanie, rozpoznawanie i reagowanie na emocje kształtuje naturę racji, która rozwija się między pacjentem a lekarzem" 27 . W tym wypadku profesjonalizm nie powinien oznaczać niezaangażowania emocjonalnego. Należy pamiętać, że obie strony interakcji posiadają emocje oraz

\footnotetext{
24 Ibidem, s. 9.

25 Ibidem, s. 12.

26 Ibidem, s. 13.

27 Ibidem, s. 15.
} 
obie te emocje komunikują (nie można bowiem nie komunikować emocji, a raczej nie dekodować ich w komunikacji), wreszcie - obaj uczestnicy interakcji na owe emocje reagują, co ma zasadniczy wpływ na ich poczucie satysfakcji, a w konsekwencji na relację komunikacyjną $\mathrm{z}$ drugim uczestnikiem interakcji.

6. Komunikacja powinna w sposób otwarty odzwierciedlać zasadę wzajemności, zgodnie z którą stopień realizacji oczekiwań jej uczestników jest negocjowany. „Lekarze i pacjenci bezustannie oceniają adekwatność wzajemnych zachowań, w odniesieniu do swoich własnych wartości i oczekiwań, oraz reagują w sposób, który - w ich ocenie — jest adekwatny, lub też, na który zasługuje zachowanie drugiej osoby"28.

7. Komunikacja powinna pomóc uczestnikom wyjść poza stereotypowe role i wzajemne oczekiwania tak, by obie strony mogły uzyskać poczucie wpływu i wolności w zakresie wymiany komunikacyjnej.

8. Komunikacja powinna wspierać rozwój relacji lekarz-pacjent, ponieważ relacja ta, sama w sobie, ma zdolność wpływania na proces leczenia i jego efekty.

Jest to model stawiający w centrum pacjenta (patient centered medicine), co w skrócie oznacza „projektowanie racji z pacjentem w odniesieniu do jego [pacjenta] potrzeb i oczekiwań" ${ }^{\prime 2}$. W modelu tym zakłada się, że podstawowymi celami komunikacji lekarz-pacjent są wymiana informacji oraz kreowanie dobrych interpersonalnych rela$\mathrm{cji}^{30}$. W oparciu na tego rodzaju założeniach ogólnych wskazuje się często podstawowe problemy i strategie poprawy komunikacji lekarz-pacjent (np. problemy: niskie kompetencje komunikacyjne lekarzy, zatajanie informacji, zachowania unikowe lekarza, zniechęcanie do współpracy, opór pacjenta; strategie poprawy: rozwój kompetencji komunikacyjnych, szkolenia i treningi, komunikacja współpracująca, świadome zarządzanie konfliktem, dostrzeganie i szanowanie punktu widzenia pacjenta ${ }^{31}$ ).

Te, nadal ogólne, zalecenia stoją u podstaw rozmaitych poradników czy przewodników dotyczących komunikacji lekarz-pacjent, a także kształtują zasadnicze elementy znacznej części literatury naukowej poświęconej temu zagadnieniu (zwłaszcza w literaturze dostępnej w języku polskim tego rodzaju ujęcie koncentrujące się na dążeniu do zwiększenia poczucia satysfakcji pacjenta przez użycie określonych środków komunikacji jest dominujące kosztem innych podejść wyraźnie obecnych w literaturze na świecie).

W ramach tak rozumianej refleksji (i będącego jej efektem poradnictwa) wskazuje się zazwyczaj na zasadnicze trudności w komunikacji lekarz-pacjent (tzw. bariery ko-

28 Ibidem, s. 17.

29 A.G. Elzubier, Doctor-patient Communications: a sill needed in Saudi Arabia, http://www.ncbi. nlm.nih.gov/pmc/articles/PMC3430176/ [dostęp: 6 marca 2016].

${ }^{30}$ H.J. van Rijjsen et al., A theoretical framework to describe communication processes during medical disability assessment interviews, http://www.ncbi.nlm.nih.gov/pmc/articles/PMC2765440/ [dostęp: 6 marca 2016].

31 Por. np. J. Fong Ha et al., Doctor-patient Communications: a review, „The Ochsner Journal” 2010, nr 10. 
munikacyjne, np. wiek, miejsce, osobowości lekarza i pacjenta, śmierć, cielesność itp.) oraz formułuje zalecenia/porady dotyczące tego, jak lekarz powinien komunikować się z pacjentem (np. używając środków komunikacji werbalnej i niewerbalnej, przez zadawanie pytań, aktywne słuchanie, podawanie ręki czy nawet mówienie po imieniu) ${ }^{32}$.

Tego rodzaju publikacjom trudno odmówić wartości pedagogicznych czy społecznych, jeśli jednak bierze się pod uwagę ich wartość poznawczą, pojawiają się zasadnicze wątpliwości. Wątpliwości te, wtórnie, muszą rzutować na możliwość praktycznego zastosowania zawartych tam zaleceń. Badania przeprowadzane wśród holenderskich lekarzy dowodzą ich ograniczonego entuzjazmu w korzystaniu $\mathrm{z}$ tego typu poradników i wskazują na wiele zarzutów, które w opinii badanych czynią te poradniki niemal bezużytecznymi (a więc takimi, z których w swojej praktyce nie korzystają). Zarzuty dotyczą np. tego, że poradniki te biorą pod uwagę jedynie interes pacjenta, że nie są w stanie poradzić sobie ze złożonością relacji lekarz-pacjent wynikającą z różnych kontekstów, cech charakteru, różnic międzykulturowych czy problemów, z którymi przychodzą pacjenci ${ }^{33}$.

Jedną z możliwych odpowiedzi na pytanie o przyczyny tego stanu rzeczy może być wskazanie na swoistą kontradykcję między postulowanym modelem komunikacji opartej na zaufaniu a specyficznymi cechami komunikacji lekarz-pacjent, które są immanentnie wpisane w tę relację, do których z pewnością należy pewien rodzaj formalizacji, dystansu, ale przede wszystkim nierównowagi i asymetryczności, co z kolei pozostaje w sprzeczności z modelem komunikacji opartej na zaufaniu ${ }^{34}$.

\section{Patient-doctor communication, and the image of physicians and public health entities}

Summary

The text is an attempt to analyse the problem of the image of health care system and its personnel (mainly doctors) in the context of communication. Author shows that the basic question in the context of doctor-patient relationship is the question of reliance and trust. Reliance is consequently the matter of communication, so the better communicative competences the doctor has, the bigger is the trust of patients form him/her.

32 Por. np. M. Hebanowski, J. Kliszcz, B. Trzeciak, op. cit.; czy też Efektywna komunikacja lekarza $z$ pacjentem wydana w ramach akcji „Leczyć po ludzku”.

33 Por. W. Veldhuijzen et al., Characteristics of communication guidelines that facilitate or impede guideline use: a focus group study, „Biomed Central”, 16 maja 2007, http://bmcfampract.biomedcentral. com/articles/10.1186/1471-2296-8-31 [dostęp: 6 marca 2016].

34 Por. K. Stasiuk-Krajewska, Komunikacja lekarz-pacjent. Dyskursywne uwarunkowania interakcji, [w:] Teorie komunikacji i mediów 7: od teorii do empirii, red. M. Graszewicz, K. Stasiuk-Krajewska, Wrocław 2014. 